\title{
The 'Botanical Gardens of the Dispossessed' revisited: richness and significance of Old World crops grown by Suriname Maroons
}

\author{
Tinde R. van Andel $\mathbb{D} \cdot$ Amber van der Velden \\ Minke Reijers
}

Received: 23 February 2015/Accepted: 2 June 2015/Published online: 9 July 2015

(C) The Author(s) 2015. This article is published with open access at Springerlink.com

\begin{abstract}
Old World crops entered the Americas as provision on slave ships and were planted by enslaved Africans in their home gardens, known as the 'Botanical Gardens of the Dispossessed'. Escaped slaves who settled in Maroon communities in Suriname's forested interior practiced shifting cultivation for centuries with seeds they brought from their home gardens. After the abolishment of slavery, Creoles largely abandoned agriculture and farming became the activity of Asian wage laborers. Maroon agriculture has never been studied in detail. The recent discovery of African rice (Oryza glaberrima) in a Maroon garden initiated this ethnobotanical study on Old World crops grown by Maroons, and their motivations for maintaining this agrodiversity. In 2013, we collected crop cultivars and landraces and interviewed 16 Aucan and
\end{abstract}

Electronic supplementary material The online version of this article (doi:10.1007/s10722-015-0277-8) contains supplementary material, which is available to authorized users.

Scientific authorities for Latin names are in Supplementary Table 2.

T. R. van Andel $(\bowtie) \cdot$ A. van der Velden $\cdot$ M. Reijers

Biosystematics Group, Wageningen University,

Droevendaalsesteeg 1, 6708 PB Wageningen,

The Netherlands

e-mail: tinde.vanandel@naturalis.nl

T. R. van Andel

Naturalis Biodiversity Center, Darwinweg 2,

2300 RA Leiden, The Netherlands
Saramaccan Maroon farmers. The greatest richness was encountered in bananas, taro, okra and rice. Most crops were used for food, but sesame, melegueta pepper and African rice largely lost their food function and served mainly for rituals. Farmers exchanged seeds and tubers with family members and other ethnicities in both urban and forest communities. Spending time in the capital during childbirth or illness resulted in the loss of typical Maroon crops (e.g., Bambara groundnut), as seeds lost viability during the farmer's absence. Motivation to grow specific crops and cultivars varied from tradition, food preference, seasonal spreading, rituals and traditional medicine. Documentation of specific landrace properties, storage of seeds in germplasm centers and in situ conservation are urgently needed to safeguard these previously undocumented Maroon landraces.

Keywords African crops - Ethnobotany ·

Landraces · Maroons · Slavery · Suriname - Traditional agriculture

\section{Introduction}

Old World crops in Suriname

The trans-Atlantic slave trade was a shipment of people and plants. Between the early sixteenth and the late nineteenth century, some 12 million Africans were shipped to the Americas in this period (Eltis and 
Richardson 2010), and along came food crops, medicinal plants, fodder grasses, as well as numerous weeds (Carney and Rosomoff 2009; Voeks 2013). These plants included African domesticates, such as African rice (Oryza glaberrima) and Bambara groundnut (Vigna subterranea), but also crops that originated in Asia but were introduced to Africa by means of the Monsoon exchange: plant transfers that took place between eastern Africa and South and Southeast Asia between $2500 \mathrm{BCE}$ and $100 \mathrm{CE}$, which transformed host societies and environments on both sides of the Indian Ocean (McNeill 2003; Rangan et al. 2012). Asian crops that were well established in Africa before the trans-Atlantic slave trade include taro (Colocasia esculenta), bananas (Musa sp.) and the pigeon pea (Cajanus cajan) (van der Maesen 1990; Carney and Rosomoff 2009). Several Old World crops (e.g., okra, Abelmoschus esculentus) are still widely cultivated throughout the Neotropics, others such as ackee (Blighia sapida) are only grown by a few AfroCaribbean communities (Rashford 2001). Some African plants blended in with the natural vegetation, like Phoenix reclinata in the coastal swamps of Suriname (Heilbron 2012), others became common weeds, such as Cleome gynandra (van Andel et al. 2012a). A few plants, like Caesalpinia bonduc in the Dutch Caribbean, even turned into invasive species (van der Burg et al. 2012). After their arrival in the New World, enslaved laborers managed to gather leftover seeds from the ship's hold (Carney 2005). Throughout the Caribbean, slaves were allowed to maintain small provision grounds at the periphery of the plantations. These home gardens, described by Carney (2009) as the 'Botanical Gardens of the Dispossessed', enabled them to grow their at least some of the familiar crops of their motherland, and became central to their physical and spiritual life (Price 1991). Traditional home gardens kept by people of African descend in the Americas, such as Cuban 'conucos' or Brazilian 'coivaras', are known to harbor high levels of agrodiversity with obsolete crop species and locally developed landraces used for food, medicinal and ritual purposes (Esquivel and Hammer 1992; De Andrade Bressan 2005).

Between the 1640 and 1830, an estimated 295,000 Africans ended up in Suriname (Eltis and Richardson 2010). Slaves in this former Dutch colony came from different regions, but major source areas were the Slave Coast (eastern Ghana to Benin), Loango (Gabon to northern Angola), the Gold Coast (Ghana) and the
Windward Coast from Guinea Conakry to Ivory Coast (van Lier 1971; Eltis and Richardson 2010). The earliest records for the presence of Old World crops in Suriname stem from the period that the country was still English property. The very first travel account, written by the British explorer George Warren (1667), mentioned 'yames' (yam, Dioscorea spp.), 'plantons' and 'bonanoes' (plantains and bananas). Almost two decades after the country became in the hands of the Dutch in 1667, the Society of Suriname requested the Governor of Suriname, Cornelis van Aerssen van Sommelsdijck, to send some exotic seeds from the colony to be grown as ornamentals in the Amsterdam Botanic Garden. In the lists of seeds sent by van Aerssen to Amsterdam, kept at the National Archives in The Hague (Brinkman 1980), the first African plants appear. Between the seeds of 21 species sent on 8 March 1685 were 'muscus zaat' (Abelmoschus moschatus), and 'okkoro' (A. esculentus). The second shipment, sent on 22 April 1686, consisted of seeds from 31 plants, among which the Old World medicinal 'palma Christie' (Ricinus communis). Soon after the first shipments of seeds, Suriname's oldest botanical collections were made around 1687 by an obscure botanist, Hendrik Meyer, who was probably hired by Governor van Aerssen. The collections consist of 50 vouchers preserved in a bound book, 'the Surinamese Hermann Herbarium' (van Andel et al. 2012b), and contain two African food crops: okra (A. esculentus) and sesame (Sesamum indicum).

Botanical gardens of the dispossessed

These early records of Old World crops in Suriname, just a few decades after the first slaves were put to work on the country's plantations provide evidence for the rapid dispersal of African crops in the New World. Contact among slaves of different plantations was surprisingly frequent (Oostindie 1993), which facilitated the exchange of crop seeds and cuttings. It is therefore not unlikely that Meyer collected these two African domesticates in a slave garden. Seventy years later, when Swedish botanist Daniel Rolander visited Suriname, these Old World crops were well established in Suriname. 'Ocrum' was cultivated in 'the gardens of the upper classes' and the 'gelatinous soup' from its fruits was eaten by 'dainty ladies' as a delicacy. Okra plants were protected by 'blacks... who bring in their gods (fetish statues) to guard and expel 
thieves... This strategy is... quite successful in keeping other blacks from laying their hands on the ocrum', Rolander noted on 18 Oct. 1755 (Rolander 2008). 'Sesamum indicum grows in all the vegetable gardens... black servants cook and eat its ripe seeds', he mentioned on 25 Oct. 1755. Rolanders observations confirm that these African food crops were actively grown by slaves, both in their own gardens and those of their masters (van Andel et al. 2012a).

Due to the poor living conditions and the brutal treatments on the plantations, many slaves decided to take the risk of fleeing into the forest. These runaways first hid themselves in temporary forest camps near their provision fields (Price 1973). After forming groups with other escaped slaves, they continued their journey into the interior, taking crop seeds and cuttings with them on their flight to freedom. Maroon oral history accounts report on rice grains smuggled to forest camps by a female ancestor in her hair (Carney 2005). The Scottish mercenary John Gabriel Stedman, who served in several military actions against escaped slaves, described how his troops encountered large rice fields and abundant stocks of cassava and yam tubers in the temporary settlements of the runaways (Stedman 1988).

Slaves who escaped from plantations in the seventeenth and eighteenth century organized themselves into different Maroon groups, of which the Aucans and the Saramaccans were the largest (Price 1973). Maroon tribes consisted of Africans of diverse ethnic origins that created new, African-American social and cultural forms. Maroon tribes consist each of several clans, descendants of groups that ran away from the same plantation, but did not necessarily have the same African origin (Price 1973). In exchange for their promise to no longer attack the plantations for food, weapons and women, they were allowed to negotiate peace with the Dutch government. In 1760 the Aucans obtained peace and recognition, the Saramaccans followed 2 years later (Price 1983; Thoden Van Velzen and Hoogbergen 2011). In their isolated forest settlements, located behind the large rapids of the major rivers, Maroons have practiced shifting cultivation for centuries and maintained much of their traditional language, culture, music and religion (van Stipriaan and Polimé 2009). Maroon culture is sometimes considered the 196 'most African of the Americas' (Herskovits and Herskovits 1934; Price 1973).
Modern agriculture and the importance of landraces

Modern agriculture makes use of cultivars, almost genetically identical crop types, mostly selected for their high yield by commercial plant breeders (Frankel et al. 1995; Maxted 2012). Landraces, differentiate from cultivars as they are selected by local farmers from natural varieties of the same species. Landraces evolved at lower levels of cultivation, fertilization and plant protection, and were selected for their hardiness and reliability, rather than their high yield. Landraces are not genetically uniform, but can be seen as populations that are in a dynamic equilibrium with their environment (Zeven 1998). Due to their genetic diversity they evolve with their environment and are less vulnerable to environmental extremes and pathogens (Frankel et al. 1995; Maxted 2012). Modern agriculture makes use of landraces to improve commercial crops, by crossing in a resistance or adapting a commercial cultivar to a different environment. Although landraces can serve as essential building stones for new cultivars and important for future crop breeding (Maxted 2012), modern agricultural technology and the introduction of new high-yielding cultivars are largely eliminating the wide range of crop genetic diversity that has evolved during the five to 10,000 years since food plants were first domesticated (Hawkes 1983).

Local farmers often maintain a diversity of crop species and landraces for their contribution to traditional dishes and dietary richness, but also for ritual or medicinal purposes (Brush and Meng 1998; Kawa 2012). In Senegal, the native African rice (Oryza glaberrima) is rapidly being replaced by its higheryielding Asian relative (O. sativa). Communities that are not converted to the Islam but hold onto their traditional beliefs, still grow small amounts of $O$. glaberrima to sacrifice to local deities to bring sufficient rain. Although these people themselves mainly eat $O$. sativa (Linares 2002), this shows how traditional culture can be of vital importance in the conservation of lesser known crop species and landraces. $O$. glaberrima was probably also the initial rice grown in many Atlantic regions, from South Carolina to Brazil. West African slaves, familiar with the techniques of its cultivation, played a crucial role in adapting the crop to diverse New World environments (Carney 2009). The recent discovery of African 
rice on a Maroon field (van Andel 2010), suggested that more 'lost African crops' were grown in Suriname's interior forests, probably along with Old World crop landraces that had never been documented before.

Maroon agriculture under threat

Maroon culture is currently under threat. The Suriname government plans to open up the south of the country by allowing Chinese companies to construct a highway to Brazil (Van Dijck 2013). Logging and mining industries have displayed interest for the natural resources in the area, which may not only have drastic environmental consequences, but also threaten the traditional livelihoods of the Maroon and indigenous tribes living in the region. The government does not acknowledge the traditional Maroon land tenure systems or their relationship with the environment (Kambel 2006). Gold mining attracts many young Maroon males looking for employment, and combined with the ongoing migration of Maroons to Paramaribo (St-Hilaire 2001), there is less labor force available for subsistence agriculture. These developments could lead to the abandonment of laborintensive food crops and landraces, while loss of traditional culture and religion may cause the disappearance of crops grown solely for ritual purposes.

Due to their isolation, Maroon agriculture has hardly been studied. The only description of Aucan agriculture was made by Geijskes (1955). Saramaccan crop rotation systems were studied in the 1970s (Budelman and Ketelaars 1974) and recently featured in a study on soil fertility management (Fleskens and Jorritsma 2010). The EU-funded development project GUYAGROFOR aimed to integrate Maroon knowledge with modern agricultural techniques to develop sustainable agroforestry systems. Although an inventory of crops planted by local farmers was part of the project, no reference to specific traditional landraces was made in any of their reports (http://www.splu.nl/ guyagrofor/). Based on missionary records and oral history accounts, anthropologist Richard Price provided a list of crops grown by Saramaccans in the 1770s, and compared these with his own observations. He concluded that escaped Saramaccans in the "early eighteenth century brought with them... the full array of crops that their descendants plant today" (Price 1991: 109). Unfortunately, he listed most crops with their local names only, without scientific identification. Although Price claimed to have documented 70 named rice varieties, 15 of okra and banana, seven yams and six of watermelon, these landraces were not preserved as botanical collections and none of their vernacular names were published.

Apart from a few African domesticates that became popular among all Caribbean citizens (e.g., okra, tamarind), coastal Creoles in Suriname abandoned the cultivation of most Old World crops as the plantation economy collapsed after slavery was abolished in 1863. Farming became the activity of Javanese and East Indian wage laborers, who preferred to grow their Asian crops. African rice (O. glaberrima) and Bambara groundnut (Vigna subterranea), crops that appear in Price's list as 'wild rice' and 'gobogobo', are now only planted by Maroons (van Andel 2010; van Andel and Ruysschaert 2011). Here we present the results of our ethnobotanical fieldwork on Old World crop richness grown by Maroons and their motivations for maintaining this agro-diversity. We hypothesized that crop diversity was maintained by farmers to guarantee food security and for their cultural importance in traditional dishes and rituals. We specifically sought for species and landraces that were getting rare and tried find the reasons behind this loss of diversity. We expected to find crop species and landraces that once must have grown frequently in the plantation periphery, but now are cultivated only by descendants of those who ran away from them.

\section{Materials and methods}

A preliminary list of potential Old World crops for Suriname was compiled from literature on African domesticates in the New World (Carney and Rosomoff 2009; Voeks 2013), earlier reports on Maroon agriculture (Geijskes 1955; Price 1991; van Andel and Ruysschaert 2011), digitized voucher images from Missouri Botanical Garden (www.tropicos.org) and (historic) Naturalis herbarium collections (Supplementary Table 1). We printed a booklet with color photographs of these plants to show our Maroon informants what we were looking for. Fieldwork among Aucan Maroons was carried out in June-July 2013 along the Tapanahoni River: mostly in the village Mooytaki, from which day trips were made to the settlements Jawsa, Tyontyon, Poowi and Karmel 
Fig. 1 Fieldwork locations and Maroon groups. 1 = Jawjaw (Upper Suriname River); 2 = Mooytaki (Tapanahoni River)

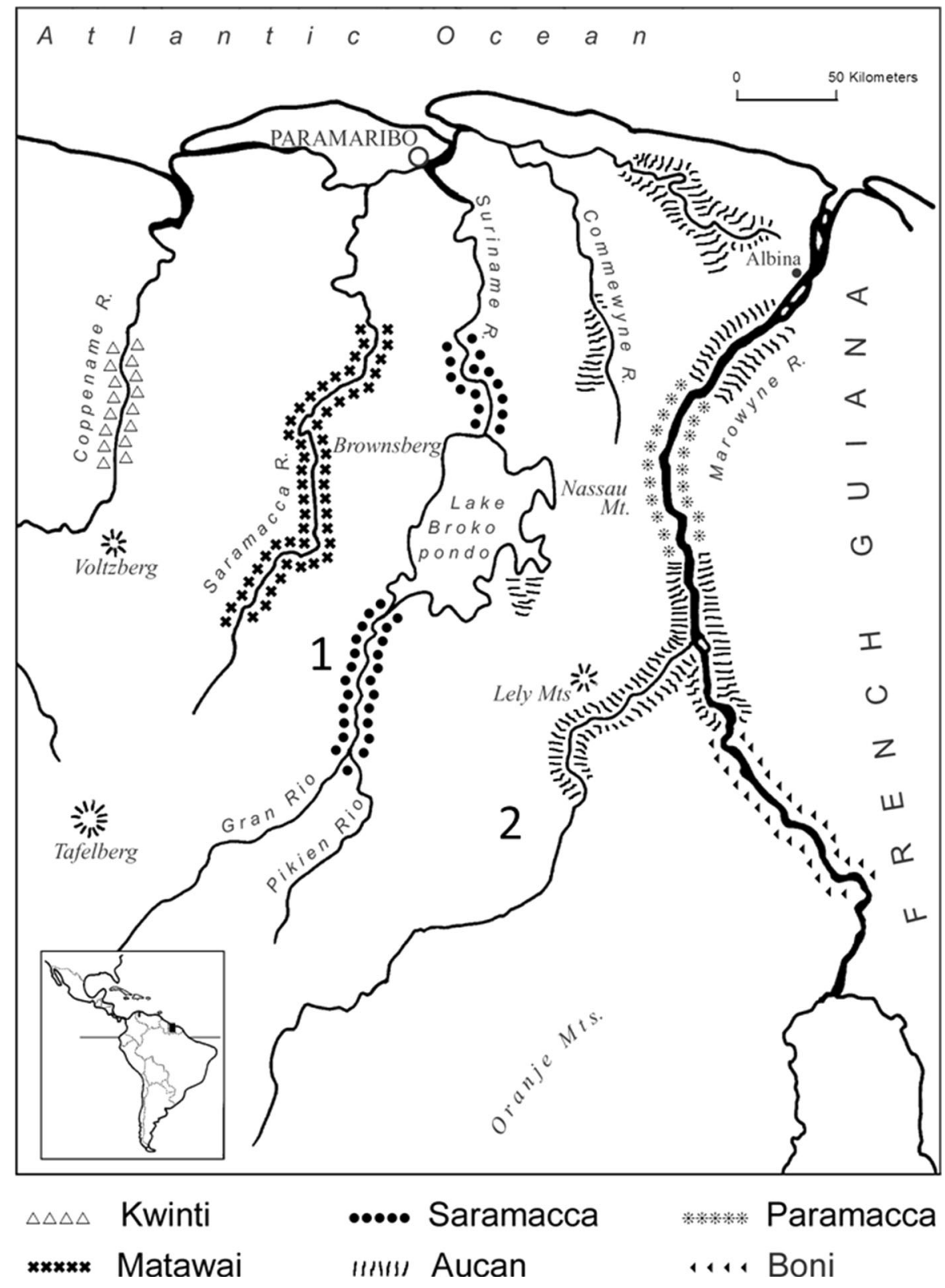

(Fig. 1). Saramaccan Maroons villages were studied in July-August 2013 along the Upper Suriname River: mainly in Jawjaw, with day trips to Lesipaansi, Gunsi, Pikin Slee and Malobi. In total, we interviewed seven Aucan farmers (all females) and visited nine of their cultivated fields. In the Saramaccan villages, we interviewed nine farmers (eight females, one male) and inspected ten cultivated fields. The age of our informants varied between 28 to over 60 years. The gender bias in our participant selection is explained by the fact that agriculture is mainly a women's task in Maroon society.

In order to document Old World crop cultivation, we accompanied Maroon farmers to their agricultural fields in the forest, their house yards and on village walks. For every individual landrace of an Old World crop, we documented the farmer's knowledge on local names, their meaning, uses, its specific phenotypical or culinary characters (habit, color, shape, size, taste, structure, etc.), propagation methods, planting and 
harvesting season, maintenance, pest an diseases, soil or water requirements, the perceived labor costs needed to grow, harvest and process the crop, and whether a specific landrace could be substituted with another for the same use purpose, such as the preparation of a traditional dish. We also asked the farmer's general questions on the reason why they grew different landraces of a crop, how they obtained their propagules and whether they knew of landraces that were getting rare and the reason for this. Interviews were held in Dutch and Sranantongo, and occasionally in Aucan or Saramaccan with the help of a local interpreter. Vernacular names were spelled (as far as possible) according to the online dictionary published by the Summer Institute of Linguistics (2003). Details on traditional Maroon dishes were published by Reijers (2014) and specific landraces used in herbal medicine were documented by Vossen et al. (2014).

All landraces of Old World crop cultivars were processed into herbarium vouchers, using standard botanical collection methods. For the majority of the collections, as far as the specific plant parts were available, we described the different landraces by completing descriptor lists provided by Bioversity International (http://www.bioversityinternational.org/). The herbarium material and descriptor lists were complemented by photographs of field characteristics (habit, color) of each landrace. To complement information on Old World crops that were not encountered in the interior, additional information and herbarium vouchers were collected from Maroon vendors at the major markets in the capital Paramaribo. Duplicates of all collections were deposited at the National Herbarium of Suriname (BBS), and the herbarium of Naturalis Biodiversity Center (L), where the specimens were identified. Further identification beyond the species level to known cultivars or landraces was done by means of the completed descriptor lists, photographs, farmer's remarks on crop properties, herbarium specimens and literature. Our identifications were verified by botanical specialists Anne Vézina (Bioversity, France) for Musaceae, Jan Siemonsma (Wageningen University, the Netherlands) for Malvaceae, Dorothea Bedigian (Missouri Botanical Garden, USA) for Pedaliaceae, Jos van der Maesen (Wageningen University) for Fabaceae and Brigitta de Wilde-Duyfjes (Naturalis) for Cucurbitaceae.
In Supplementary Table 2 we have listed all landraces of Old World crops as distinguished by the farmers we interviewed, with their scientific names, local names, voucher numbers, distinguishable characters attributed by farmers. We added corresponding cultivar names as far as these could be matched by means of the descriptor lists, literature, and information from botanical experts.

\section{Results}

Old World crop species in Suriname

In the two Maroon areas, we recorded 27 different Old World crop species, represented by 120 botanical collections, counting all banana collections (Musa spp.) as one species (Supplementary Table 2). There was a considerable overlap (18 species) in Old World species grown by Aucans and Saramaccans. The Aucans cultivated two crops (Ricinus communis and Abelmoschus moschatus) that were not encountered among Saramaccans, while the latter grew six species that Aucans did not (Aloe vera, Cajanus cajan, Vigna subterranea, Hibiscus sabdariffa, Aframomum melegueta, Solanum macrocarpon). Our list of Old World crops to be expected in Suriname (Supplementary Table 1) contained 41 species, of which 17 were not observed during our study. Some of these species were grown only by Surinamers of mixed descend on former plantations in the coastal region (e.g., hyacinth bean, Lablab purpureus) or in urban areas, like the tamarind tree (Tamarindus indica). Some Old World crops that were once grown in Suriname can now be considered as extinct, as they are not represented by recent herbarium vouchers and absent from the region's botanical checklist (Funk et al. 2007). An example is the West African cola nut (Cola acuminata), once collected by the Dutch botanist F.A.F.C. Went on the plantation Jagtlust in 1901. Others were observed by Rolander in 1755 on coastal plantations, but not represented by surviving herbarium collections, such as the medicinal plants Solanum incanum and Croton tiglium (Rolander 2008). Some Old World crops have lost their role as food crop and now only survive as weed in disturbed areas, like the African cabbage Cleome gynandra, in 1755 widely cultivated as a vegetable in Paramaribo gardens (Rolander 2008; van Andel et al. 2012a). Several African species never 
arrived or survived in Suriname, but did so in other Caribbean countries, like Xylopia aethiopica in Cuba and Sorghum bicolor in the Dutch Antilles (Esquivel and Hammer 1992; van Proosdij 2012).

\section{Bananas and plantains}

The greatest diversity in Old World cultivars was encountered in bananas and plantains (Musa sp.), for which we distinguished 17 officially described cultivars and one landrace (taángáháti) that could not be identified to cultivar level (Supplementary Table 2). Of our 18 types of bananas, 11 were cultivated by Aucans, ten by Saramaccans, while for only three cultivars we could ascertain that they were shared among the two Maroons groups. All sweet bananas (dessert type) were said to have their own specific taste. Most cooking bananas could be used interchangeably for a large variety of traditional dishes, although Aucans preferred the somewhat sour-tasting 'suwasuwa baana' to make 'tonton baana' ( $\mathrm{Au}$ ), a traditional dish from boiled ripe plantains mashed with a little salt into a porridge-like substance (Reijers 2014). Saramaccans drank tea from the leaves of the 'toto baana' (probably the red Dacca cultivar, but we did not observe ripe fruits) against high blood pressure and used them in herbal baths to ritually cleanse the family members of a recently deceased person and in poultices to heal fractures (van Andel and Ruysschaert 2011). Aucans used leaves of the dwarf Cavendish cultivar 'wataa mama bakuba' in herbal baths to stimulate their children to walk early (Vossen et al. 2014). The Aucan 'patankele' and the Saramaccan 'apantakëé', both stout, triangular, bluggoe type plantains could be the same cultivar, and possibly correspond with the 'lowéman baana' (plantain of the runaway slaves), that was collected by Heilbron (2012) on the abandoned plantations near Bakkie in the coastal Commewijne district. All were triploid ABB cultivars $(1 \times M$. acuminata, $2 \times M$. balbisiana), but the collections from Bakkie contained a few seeds. Although the name 'sipi baana' refers to a plantain that came with a ship, it is not certain which banana cultivars grown by the Maroons today were brought to Suriname during the trans-Atlantic slave trade and which types were introduced later by Asian wage laborers. Several local names for banana or plantain types that appeared in literature could not be matched with collections, since the Maroons we interviewed did not know them. Examples are the
Saramaccan 'benteo-pu-bakuba' and the ritually used 'dungulali tabaka' (Van Andel and Ruysschaert 2011) and the 'asubusúba', a Saramaccan plaintain with a thick skin (Summer Institute of Linguistics 2003). These names might either refer to undocumented landraces or just represent local names from other Maroon villages for the cultivars that we did collect. More extensive botanical collections and genetic studies on the different banana cultivars are needed to clarify the diversity and exact geographic origin of the Surinamese bananas and plantains.

\section{Taro}

We documented quite a variety of taro (Colocasia esculenta), but we could only link one of the 12 landraces to an official cultivar (Supplementary Table 2). There exist two cultivar-groups of taro: the dasheen group, sometimes known as C. esculenta var. esculenta (Burkill 1985-2004), with a single large corm producing few small cormels and the eddoe group, frequently classified as $C$. esculenta var. antiquorum, producing many large cormels, which are the main product (Safo Kantaka 2004). Not all of our collections contained mature corms, and even with the farmer's knowledge, it was not always possible to assess whether they would produce a single or multiple cormels later on. Some Saramaccan landraces were mentioned to us, but we did not encounter them in the field. Local farmers, however, did use the term 'dashini' (Au) or 'dasíni' (Sa) for some of their landraces. Based on farmer's classifications and our observation on morphological similarities (size and colors of leaves and cormels), we grouped our Colocasia landraces into a minimum of nine and a maximum of 12 landraces, belonging to eight dasheen types and four eddoe types. Only the purple spotted 'penipeni dashini' could be linked to the known cultivar Bun-long from Hawaii (Whitney et al. 1997). Saramaccans and Aucans each cultivated ca. seven different varieties, but based on our voucher material, they shared only two. Although farmers mentioned that some of the Colocasia landraces tasted different than others, they were all used in a similar way as a starchy staple food and soup ingredient (Reijers 2014). The Aucan landrace 'blaka dashini' is probably the same as the 'paarse dasíni' (purple dasheen) mentioned by Saramaccans, for which no individual was available to make a botanical collection. These two 
landraces, of which the starch was said to become blue after cooking, may be similar to the Blue Metal variety that is cultivated in Tobago for the blue food festival, but even this cultural keystone landrace lacks a proper scientific description.

\section{Okra}

Based on the size, shape and color of leaves, flowers and fruits, we distinguished 11 landraces of okra (Abelmoschus esculentus). Aucans cultivated more landraces (nine) than Saramaccans (six), and also had more vernacular names for them, mainly referring to the time it took for a plant to produce its first fruit. Both Aucans and Saramaccans distinguished landraces that took only 3 weeks to fruit ('dri wiki') or 6 weeks ('siksi wiki'), but Aucans also grew a 7-weeks, a 3 month, a fast fruit-producing type ('haste maker') and one that took longer ('slow maker'). Saramaccans called most of their landraces simply 'lalú' (okra). When we asked what type of okra they meant, they replied 'normal okra'. The groups of landraces we distinguished based on morphology did not entirely coincide with the farmers' own classification, as is shown in Supplementary Table 2. The Saramaccan 3-week okra was similar in appearance to one of the Aucan 7-week okras. According to okra specialist Jan Siemonsma (pers. comm.) there was likely not much genetic variation in the Maroon okra landraces. Although cross-fertilization sometimes takes place in A. esculentus, most okra's are self-pollinated. He considered the Maroon landraces as cultivar groups, relatively stable because of their selfpollination. However, in insect-rich environments, cross-pollination in okra can be up to $19 \%$, and in some cases even over $40 \%$ (Tripathi et al. 2011). Given the rainforest environment of the Maroon fields, it remains possible that the landraces encountered during our study were domesticated further after the crop arrived in Suriname. They did not resemble specific commercial cultivars, although some landraces showed similarities with the cultivars 'Clemson spineless' and 'Emerald'. Maroon farmers aid that all types of okra tasted similar and were used for the same purpose: the famous Surinamese okra soup (Reijers 2014).

Yam

Both Maroon groups cultivated mainly the Neotropical species 'napi' (Dioscorea trifida), for which they distinguished several varieties. This species was grown by indigenous people in Suriname before the arrival of African slaves. The two Old World species of yam (D. alata and D. cayennensis subsp. rotundata) were grown to a lesser extent by both groups, but Saramaccans grew more spiny yam (D. cayennensis subsp. rotundata) than Aucans. Typically, the Aucan name for the spiny species ('logo saamaka nyamsi') meant 'type of yam brought by Saramaccans'. All leaves and inflorescences of the five $D$. cayennensis subsp. rotundata individuals we collected looked very similar and our informants did not distinguish different types of spiny yam. As there were no fully grown roots present at the time of our fieldwork or the owner did not give us permission to dig them up, we could not ascertain whether they had yellow or white flesh, typical to certain cultivars (Howard 1979; Onwueme and Hamon 2002).

Dioscorea alata was hardly cultivated, but we observed it regularly growing wild around Aucan and Saramaccan house yards. According to our informants, the plant was an 'ancestor food', once cultivated but now a weed that was hard to remove. Any discarded piece of tuber could grow back to a large vine. A Saramaccan farmer from Gunsi said she planned to dig out all the tubers and throw them in the river, to get rid of the massive vine bushes around her house. The overlapping leaf lobes of this yam type, its white elongated, unbranched, fleshy tuber that quickly oxidized to orange, and discarded pieces that quickly grew back, corresponded with the 'wild type' of yam described for Trinidad (Gooding 1960). All types of yam were boiled with meat or fish in soup. Yam roots were sometimes baked and boiled yam was occasionally pounded with some salt and oil in a mortar into a firm dough ball, called 'afufu' (Au) or 'fufu' (Sa) and eaten with a spicy sauce (Reijers 2014).

\section{Beans}

While Aucans only planted the common yard long cultivar of Vigna unguiculata (Sesquipedalis group), Saramaccans grew four different cultivar groups, which were easily identified by the length of their pods, the number of ovules per pod and the space between the seeds, using the descriptions by Maxted et al. (2004) and Maréchal et al. (1978). Within the cultivar groups there exists still a variation in seed color and patterns. The Maroon landraces could not 
directly be linked to existing commercial cultivars such as those sold by commercial growers and advertised on the internet. A single pigeon pea shrub (Cajanus cajan) was encountered in the Saramaccan village of Jawjaw, of which the beans were cooked as vegetable. We could not assign a cultivar name, as this individual shrub had not yet produced ripe seeds. Aucans, and to a lesser extent Saramaccans, cultivated velvet beans (Mucuna pruriens) as a coffee substitute. The seed coat was removed and the beans were roasted, ground, sieved and dissolved in hot water with sugar and milk. Our informants preferred this coffee above ordinary Nescafé. Saramaccans also used the ash of burned seeds as a medicine for skin burns. None of these practices are known among non-Maroons in Suriname.

Aucan farmers did not recognize the Bambara groundnut (Vigna subterranea), but it was well-known as gobogobo among Saramaccans, although not often cultivated. Two of the nine Saramaccan farmers we interviewed had seeds in stock that were too old to be planted. Bambara groundnuts were cooked and eaten as vegetable, and said to be healthy and tasty. The living plant was only encountered twice, grown in small amounts in house yards to increase the seed stock. Farmers ensured us that seeds should be planted each year, otherwise they no longer germinated. One farmer told had been ill during the harvest period of her Bambara groundnuts, which had caused the loss of her entire seed stock. V. subterranea was probably always rare in Suriname, as our voucher was the second accession in the Leiden herbarium since Splitgerbers collection of the species in 1858 (Supplementary Table 1).

\section{Sesame}

Both the white (Sesamum indicum) and the black sesame ( $S$. radiatum) were cultivated by the two Maroons groups. White sesame was actively sown in cultivated fields or house yards, while black sesame was growing more like a weed in vacant patches in the village or on abandoned fields. Farmer's information on the use of this crop was somewhat contradictory. One Aucan farmer said that in the past, white sesame seeds were roasted and pounded into a peanut butterlike paste called 'ansowe' (Au), but this custom had died out along the Tapanahoni. A Saramaccan farmer said that some Maroons sold the white seeds to the bread factory in Paramaribo. The black seeds were never eaten. No oil was produced either. According to the farmers, the seeds of both sesame species could be stored only for 1 year, after which they lost their ability to germinate. Both sesame species had lost their primary function as a traditional food crop, but their role in Afro-Surinamese rituals was still prominent. Maroon vendors sold both black and white seeds in bags of ca. $0.3 \mathrm{~kg}$ at the medicinal plant market in Paramaribo. The seeds were sprinkled around the house at night to ward off vampire spirits or 'evil people who say bad things'. The West African vampire spirit, known in Suriname as 'azeman', enters the house at night in the form of a ball of fire to drink the blood of innocent people. When he notices the seeds around the house, he is obliged to count them all before he can enter. As this will take a long time, sunrise will surprise him and chase him away (van Andel and Ruysschaert 2011). Fresh bundles of the strong-smelling leaves of both species were sold at the same market and used in ritual baths to chase away evil spirits. A similar myth connecting sesame seeds to vampire spirits is known throughout the Black Caribbean, while counting sesame seeds was documented as a ritual punishment in Sierra Leone (Bedigian 2013).

Rice

Next to bitter cassava (Manihot esculenta), which is consumed as toasted grains ('kwak') by Aucans or baked into flat cakes ('kasába bëëë') by Saramaccans, rice is the main staple food of the Maroons. It forms part of the daily meals and figures in many traditional dishes (Reijers 2014). Although almost all farmers had one or more fields of upland rice, they said that the crop was cultivated more intensively in the past than it was now. Rice was considered to be a labor-intensive and time-consuming crop. Most farmers said they cultivated smaller amounts of rice than their ancestors did, and supplemented their staple with milled rice purchased in Paramaribo or in local shops. Several explanations were given for the decline in rice production. An Aucan woman in her forties stated that: "There is less rain now than before. Rice cannot survive the drought, therefore less rice and more cassava is grown". Another Aucan farmer said that the planting, harvesting and milling of rice was a lot of work, so she preferred to grow less rice and 
supplement this by shop rice that was already milled. When we arrived in the Tapanahoni, the Aucans had already harvested all their rice. We managed to make some collections from seeds kept at people's home and leftover plants (Supplementary Table 1). In the Upper Suriname River, however, we arrived at the height of the rice harvesting season. Aucans sowed their rice in December and harvested in April, while Saramaccans sowed in March and harvested in July-August. As the climate and soils in the two Maroon territories are comparable, the difference in growing season may be either attributed to different landraces or different cultural practices.

As our focus was on Old World crops, we were mostly interested in African rice (Oryza glaberrima) and less in Asian rice (O. sativa), which is generally considered as an Asian crop that was recently introduced to Suriname. African rice was only grown by two of the 16 farmers we interviewed and seemed to hold a unique position. It was planted in small amounts next to other rice varieties. Some informants (both Aucan and Saramaccan) considered the crop suitable for consumption, which required extra labor, as black rice cannot be milled mechanically and needs to be dehusked by hand with a mortar and pestle. Others grew it solely for medicinal and ritual purposes. One Saramaccan farmer said: "Black rice is only used by Maroons; it is not suitable for marketing". Still, the grains were sold at the medicinal plant market in small bags of ca. 100 grams, to be used in ritual baths or food offerings to the ancestors (van Andel and Ruysschaert 2011), boiled as tea against skin rashes (Reijers 2014) and sprinkled on newly cut agricultural fields before burning to ensure a better harvest.

In 1863, after the abolishment of slavery, the Dutch contracted East Indian and Javanese farmers to work on the plantations as contract labourers. These migrants introduced many Asian crops, including several rice cultivars that they started to plant on their private fields along the Surinamese coast. In the early twentieth century, large scale rice cultivation started in newly developed polders in eastern Suriname (Ostendorf 1962). Both Aucans and Saramaccans grow a considerable number of Oryza sativa types. We have documented their local names and when grains were available, made collections. Since most vernacular names were Maroon, we do not know whether they correspond with commercial cultivars or Asian landraces that are grown elsewhere in the country, except for the cultivars that Maroons called 'breuk 2' and 'breuk 3' and two types named 'kuli alisi', which means 'rice of the East Indians'. Very few Surinamese rice collections exist in the Naturalis herbarium. The other Maroon $O$. sativa types may either have a recent Asian origin or they could have come from Africa during the trans-Atlantic slave trade. Locally produced rice was frequently bought by slave traders to feed their living cargo (Carney 2009). These purchases were frequently mentioned in logbooks of ship captains (Zeeland Archives 2013), but no distinction was made between the types of rice bought from African merchants (Carney 2005).

In total, we documented 25 landraces of $O$. sativa, of which 12 were grown by Saramaccans and 17 by Aucans. Some of these landraces may be grouped together, but due to the absence of ripe grains we were not able to make collections of all types mentioned to us. It is likely that this richness is just the tip of the iceberg. Geijskes (1955) mentioned 22 Aucan names for rice landraces, of which only six coincide with names that we documented. If $O$. sativa was only introduced to Suriname after the Maroons had fled into the interior, we would have expected the Maroons to cultivate a much lower variety of rice, and show more overlap in the types cultivated. Given the large variety of Maroon rice types, the detailed vernacular classification and the importance of this crop in their daily lives, we hypothesize that $O$. glaberrima and a variety of $O$. sativa landraces entered Suriname by means of slave ships. One of the earliest historical observations of rice in Suriname were made by (Herlein 1718), who mentioned that "rijs" was sown in the country along with sugarcane, peas and maize. The Scottish mercenary John Gabriel Stedman, who was engaged in several military actions against escaped slaves, described how his soldiers found extensive rice fields and baskets of milled rice in the deserted forest camps of the runaways (Stedman 1988). Physical evidence for the presence of Asian rice in Suriname was supplied by Rolander (2008), whose diary entry on the 13th of September 1755 reports: "Oryza sativa was found by chance among coffee plants on a certain plantation, though the residents didn't even know its name. Grains are not sown in these lands; they are all imported from North America instead...". Rolanders voucher of this rice plant is preserved in the Bergius herbarium in Stockholm (http://info.bergianska.se/ bilder/bergius/12/12898oryzsat1.jpg). It is not 
surprising that the plantation owners were not aware of the rice was grown on their lands, as it was probably grown secretly by their slaves (van Andel et al. 2012a).

\section{Other Old World crops}

The bottle gourd Lagenaria siceraria was represented by two, slightly differently-shaped landraces: 'pu' $\mathrm{Au}$ ), of which the young fruit was boiled and eaten as a vegetable and 'golu' (Sa), said to be unsuitable for consumption. Both fruits were used as bowls when dry. At the time of our fieldwork, only dried fruits were present. L. siceraria was said to be harvested in January or February, so the vine itself already died and we could not document any morphological differences in the leaves or flowers.

Melegueta pepper (Aframomum melegueta) is commonly traded throughout West and Central Africa for their use in spice and medicine (Andel et al. 2012c; Quiroz et al. 2014; Towns et al. 2014). In Suriname, the seeds are no longer known as spice, but used by both Maroon groups in (ritual) herbal medicine. Chewed seeds are spat on a baby's fontanel to prevent evil spirits from entering the child's body (Vossen et al. 2014). The plants is known as 'nengrekondre pepre' (litt. negroe-country pepper), acknowledging its African origin. Aucans said they had tried to grow the plant but the seeds did not germinate, so they bought the fruits for $€ 2$ in Paramaribo. Saramaccans knew the plant could only be propagated by its rhizome, but we only found one individual in the village of Gunsi. The owners of the plant sold the fruits, but were not willing to share its rhizomes.

The musk okra (Abelmoschus moschatus) was only observed in Mooytaki. Aucans planted it around a cultivated field to ward off capybara's that came to feed on the crops at night. The leaves with irritating hairs are used in herbal baths to ward of spirits of recently diseased people (van Andel and Ruysschaert 2011). Although people remembered to have drunk the red lemonade from the boiled calyces in their childhood, Hibiscus sabdariffa was not commonly cultivated anymore. A green-leaved cultivar was encountered twice along the Upper Suriname, while a red-leaved cultivar was only recorded from the Saramaccan village Nieuw Lombé on the Lower Suriname River.

Eleusine indica grew wild in open areas, but was also planted or carefully spared from weeding in both
Aucan and Saramaccan house yards. The grass was used in ritual baths, mostly to encourage children to walk early (Vossen et al. 2014). Elaeis guineensis was cultivated in both Maroon villages. The fruit flesh was consumed raw, but some farmers knew that an oil ('obe fatu', Au) could be obtained by drying the seeds in the sun, cracking them open, pounding them and boiling them in water, after which the oil could be scooped off (Reijers 2014). None of our informants had ever heard of producing palm wine from this species. This African practice must have died out recently in Suriname, as General Johannes van den Bosch (1818:41) mentioned: “These Negroes, also called Maroons, have created several small republics in the interior. They all go naked, but live in prosperity. They always have palm wine in abundance, which they gather by cutting a square foot in the [palm] trunk, of which they collect the sap in a bowl."

Farmer's motivation to maintain crop diversity

Our data show that some Old World crop species like bananas, okra and taro were much appreciated by Maroons, who planted a wide variety of landraces, some of which coincided with officially recognized cultivars. This also accounted for Oryza sativa, although further genetic research is needed to verify which of these rice varieties are African landraces introduced during the trans-Atlantic slave trade and which are recently introduced Asian cultivars. For 89 of the 162 botanical collections (including New World crops), the 16 interviewed farmers supplied information on the provenance of their stock of seeds, tubers or rhizomes. In $80 \%$ of the cases, farmers had obtained propagules from their family members (mostly their mother), or from Maroons in their near surroundings. In 12 cases $(13 \%)$ they had bought the seeds in Paramaribo. This does not necessarily mean that these propagules were commercial cultivars sold by agricultural companies, as hundreds of Maroon women sell garden produce on the streets of Paramaribo. In fact, ten landrace collections were sold by our farmers themselves in town. A few farmers said they bought tubers from East Indian and Javanese farmers on the market to bring back to the interior as planting material. Most farmers indicated that they were willing to share, barter or sell their propagules with other villagers. One 35-year old Aucan woman said she had Amerindian friends, from whom she obtained 
a large plantain cultivar ('dugubaana'), 'which was not planted before by our ancestors' and a purple landrace of Dioscorea trifida ('ingi napi'). She said she was the only one in the village who had this connection with Amerindians living upriver, and they mostly wanted rice in return for their yam and banana propagules. All farmers stored a fraction of their seeds (or tubers) as planting material for the following year. Bananas, however, 'would grow by themselves and do not need planting', and African oil palms 'were old trees that could produce for years so it is not necessary to plant them'.

Tradition was the main motivation to grow specific crops and landraces: "my parents grew this type and that's why I also do it'. Personal food preference ('I find this type tastier than the others') ranked second. For one Aucan farmer, spreading food availability over the year was the reason for cultivating many okra landraces with distinct fruiting periods. She did not share their seeds with others, so she could sell okra to her neighbors when they had none. Most traditional dishes that contained rice, okra, banana or taro could be made with several different landraces (Reijers 2014). Only in a few cases, a dish required a particular crop type, like the sour plantain to make 'tonton baana'. In herbal medicine and rituals, however, specific Old World species and landraces were essential and grown solely for this purpose. Only African rice could be used in rituals to ensure a good harvest, while leaves of specific banana cultivars were required in herbal medicine. Sesamum radiatum leaves were macerated with garlic, lime leaves and Senna occidentalis into a slimy herbal bath to ritually cleanse someone from bad luck and accidents. Our hypothesis that Old World crop diversity was maintained by farmers to guarantee food security and to prepare traditional dishes and specific rituals was therefore only partly accepted.

Old World crops that are becoming rare

Rice was perceived as a particularly labour-intensive crop. Farmers stated that the unreliable weather negatively influenced the harvest and birds ravaged their fields. Some informants indicated that larger quantities of rice were sown in the past, and women now complemented their home-grown rice with that bought in shops or planted bitter cassava instead. The introduction of mechanical rice mills elsewhere in the
Americas has caused the shift from $O$. glaberrima (which needs to be dehusked by hand with a wooden mortar and pestle) to O. sativa, of which the grains do not break during mechanized milling (Carney 1998). In Mooytaki, there was an electric mill for which women had to pay ca. US\$ 2 per bucket of rice. This kept a considerable number of women from using the machine, as they preferred to save money and dehusk the grains by hand. In almost all household there was a wooden mortar and pestle present. An Aucan farmer remembered that also in the past, black rice was not grown in large quantities 'because it was never eaten'. As long as Maroons feel the need to offer 'first-time food' to their ancestors and the sale of African rice provides a source of income, there is future for $O$. glaberrima in Suriname, although its role as an ingredient in traditional dishes may disappear soon. We witnessed several Saramaccan funerals, but we did not observe black rice (or any specific type of homegrown rice) being used in funeral dishes, as was the custom in the 1970s (Price 1983).

The African species of yam (Dioscorea alata and D. cayennensis subsp. rotundata) were losing ground to the New World D. trifida, of which many different landraces were grown. Opinions on yams differed among farmers. While an Aucan respondent said that 'dog yam' (D. alata) was popular among the ancestors but now only eaten 'by dogs and Saramaccans', her neighbor grew the same yam species for her soup, did not considered it an old-fashioned crop and neither called it 'dog yam'. A Saramaccan farmer that grew the same yam species agreed that it was rare, but refused to share it with others. While the consumption of this 'ancestor yam' may soon be forgotten, the plant itself will not disappear, as it easily survives as a weed around villages. Apart from the farmer's remarks on ancestor yam, however, we have no evidence that African species of yam were more frequently cultivated in the past than they are today. Historic sources mention yam cultivation (e.g., Warren 1667; Stedman 1988), but they never distinguish between the different species of the genus Dioscorea.

The 'gobogobo' (Vigna subterranea) was said to become rare because its seeds quickly lost their ability to germinate. Women who did not plant this crop every year would lose their crop, unless they had access to new, viable seed stock. These groundnuts were not for sale in Paramaribo. American peanuts (Arachis hypogaea) were grown in large quantities, 
and probably replaced this crop. Farmers had tried to sow the seeds of Aframomum melegueta, but they did not germinate. The few who possessed a plant were unwilling to share some of its rhizomes. A Saramaccan traditional healer in Jawjaw was growing the Asian ornamental Alpinia zerumbet in his yard. Although he knew that this was not the true 'nengrekondre pepre', he sold the fruits to his fellow villagers, who apparently did not remember the exact appearance of A. melegueta. The seeds of this ginger-like plant are essential ingredients in ritual medicines for newborns (Vossen et al. 2014) and figure in strengthening baths for men before they cut open a field. Apparently, A. melegueta had become so rare that people forgot what it looked like. A major reason for not planting a field every year was an increasingly easier access to the city by road, boat and airplane. Women often spent time in Paramaribo during illness or to give birth. Although the farmers brought newly acquired crops home when returning to their villages, their stocks of typical Maroon crops with limited seed viability would be gone during their absence. As an Aucan farmer in her thirties explained: 'Other years I did not have 'ingi napi' (Dioscorea trifida), as I was busy with my baby.' An elderly Saramaccan woman stated: 'I was in the city because I was ill and then I could not plant and harvest my 'gobogobo'. Now the seeds are too old to grow.' The loss of viability of these seeds is probably caused by genetic erosion.

\section{Discussion}

The Maroon farmers in this study did not distinguish between Old and New World crops. Traditional dishes hardly ever consisted of Old World crops alone, but were often a mixture of ingredients of Old and New World origin. Portuguese traders introduced American crops like cassava, maize and peanuts to Africa around 1500 , so these crops were well established before the onset of the trans-Atlantic slave trade (Alpern 2008; Voeks 2013). Several farmers we interviewed were aware that some crops were getting lost, but did not link these crops directly to their ancestors. Our research should not be seen as representative for the entire Maroon region. Further research in more remote villages and other Maroon groups may yield more Old World landraces that we did not encounter during our study sites. Fieldwork in the planting season from
December to March, for example, may yield data on crops that already had been harvested when we were present (June-August), such as pumpkins, watermelons, gourds and Aucan rice varieties. Fieldwork from September to November, on the other hand, would be better to collect root crops (yams and taro), which were not fully grown at the time of our visit. The conclusion of Price (1991) that 'escaped Saramaccans in early eighteenth century brought with them the full array of crops that their descendants plant today' is probably not true, given the active exchange of propagules by Maroons with other ethnic groups.

Bananas are relatively well-studied, sterile clones, which made cultivar identification relatively easy, using literature and online pictorial keys (www. promusa.org and www.musarama.org). For the other Old World crops, it was more difficult to link Maroon landraces to official cultivars. Although descriptor lists provide detailed guidelines for the documentation of crop morphological characters, they lack keys to landrace or cultivar names. Voucher collections of cultivated crops are rare, but landraces are even less represented in herbaria. The scanty documentation on locally grown crops in Suriname, the absence of their propagules in international seed banks and the fact that some crops and landraces are only cultivated in remote areas, are strong arguments for the conservation of Maroon crop diversity. This could happen by means of ex situ conservation on experimental farms, combined with the storage of seeds and vegetative material at low temperature in germplasm centers. A disadvantage of this method is that when these seeds are planted again, there is no guarantee that the crops will be resistant against the evolved pathogens and the environment (Altieri and Merrick 1987). Scientific documentation of specific cultivar properties is needed, including DNA analysis on their interrelatedness and geographic origin. As some Old World crops that are still grown by Surinamese Maroons have become extinct in other parts of the Americas (e.g., African rice and Bambara groundnut), their current seed stock could yield interesting source material for modern agriculture. On the other hand, for some Old World crops, Maroon fields are not as diverse as home gardens elsewhere in the Americas. In Cuba, much more varieties of Vigna unguiculata were grown than in Suriname (Esquivel and Hammer 1992). In home gardens of 'quilombos', descendants of escaped slaves in Brazil, De Andrade Bressan (2005) found a huge 
amount of African yam landraces: 16 for Dioscorea alata and 21 for D. cayennensis subsp. rotundata.

In situ conservation, in which landraces are preserved by growing them in their original environment, allows them to co-evolve with their local pathogens and climate conditions (Esquivel and Hammer 1992). This way of conservation provides a continuous source of germplasm, with which to upgrade advanced cultivars (Brush and Meng 1998). Future agricultural development projects in Maroon villages should also be aware of the value of their unique landraces and think twice before advising to replace traditional crops with new, high-yield varieties. Promoting the cultivation of 'first-time crops' would create awareness among Maroons on the value of their traditional agriculture. In the end, they are still the sole guardians of many crops that their ancestors once grew in the Botanical Gardens of the Dispossessed.

Acknowledgments We are grateful to all Maroon farmers who shared their knowledge to us. In particular, Thomas Polimé and Berto Poeketie facilitated fieldwork in the villages of their families. This research was funded by the Netherlands Organization for Scientific Research (ALW-Vidi Grant Nr. 864.09.007). Student participation was financed by the Alberta Mennega Stichting and the Van Eeden Foundation.

Conflict of interest The authors declare that they have no conflict of interest.

Ethical standard Research involving Human Participants: In all our fieldwork locations, we first discussed the nature of our research with village elders and/or school teachers, after which participants were selected and/or volunteered. Participants signed a document of prior informed consent and obtained a modest remuneration for their contribution. Prior to our fieldwork, we obtained a permit for the collection and export of herbarium samples from the Suriname Forest Service. In the project, the authors followed all guidelines of the Code of Ethics of the International Society of Ethnobiology (http://www. ethnobiology.net/what-we-do/core-programs/ise-ethics-program/ code-of-ethics/) to ensure ethical conduct in the design, implementation, and publication of their research. We ensured participants' confidentiality by anonymizing their identities in databases and publications.

Open Access This article is distributed under the terms of the Creative Commons Attribution 4.0 International License (http:// creativecommons.org/licenses/by/4.0/), which permits unrestricted use, distribution, and reproduction in any medium, provided you give appropriate credit to the original author(s) and the source, provide a link to the Creative Commons license, and indicate if changes were made.

\section{References}

Alpern S (2008) Exotic plants of western Africa: Where they came from and when. Hist Afr 35:63-102

Altieri MA, Merrick LC (1987) In situ conservation of crop genetic resources through maintenance of traditional farming systems. Econ Bot 41:86-96

Bedigian D (2013) African origin of sesame cultivation in the Americas. In: Voeks RA, Rashford J (eds) African ethnobotany in the Americas. Springer, New York, pp 67-122

Brinkman J (1980) Surinaamse planten in Nederland in de zeventiende eeuw. MSc thesis, Utrecht University

Brush SB, Meng E (1998) Farmers' valuation and conservation of crop genetic resources. Genet Resour Crop Evol 45:139-150

Budelman A, Ketelaars JJMH (1974) Een studie van het traditionele landbouwsysteem onder de boslandcreolen. Paramaribo, Suriname

Burkill HM (1985-2004) Useful plants of West Tropical Africa 1-6. Royal Botanic Gardens, Kew

Carney JA (1998) The role of African rice and slaves in the history of rice cultivation in the Americas. Hum Ecol 26:525-545

Carney JA (2005) Rice and memory in the age of enslavement: Atlantic passages to Suriname. Slavery Abolit 26:325-347

Carney JA (2009) Black rice: the African origins of rice cultivation in the Americas. Harvard University Press, Boston

Carney JA, Rosomoff RN (2009) In the shadow of slavery: Africa's botanical legacy in the Atlantic World. University of California Press, Berkeley

De Andrade Bressan E (2005) Diversidade isoenzimática e morfología de inhame (Dioscorea spp.) coletados em roças de agricultura tradicional do Vale do Ribeira, Sao Paulo. Thesis, University of Sao Paulo, Piracicaba, Brasil

Eltis D, Richardson D (2010) Atlas of the trans-Atlantic slave trade. Yale University Press, New Haven

Esquivel M, Hammer K (1992) The Cuban homegarden "conuco": a perspective environment for evolution and in situ conservation of plant genetic resources. Genet Resour Crop Evol 39:9-22

Fleskens L, Jorritsma F (2010) A behavioral change perspective of Maroon soil fertility management in traditional shifting cultivation in Suriname. Hum Ecol 38:217-236

Frankel OH, Brown AHD, Burdon JJ (1995) The conservation of plant biodiversity. Cambridge University Press, Cambridge

Funk V, Hollowell T, Berry P, Kelloff C, Alexander SN (2007) Checklist of the plants of the Guiana Shield. Contrib US Natl Herb 55:1-584

Geijskes DC (1955) De landbouw bij de bosnegers van de Marowijne. West-Indische Gids 35:135-153

Gooding HJ (1960) West Indian Dioscorea alata cultivars. Trop Agric Trinidad 37:11-30

Hawkes JG (1983) The diversity of crop plants. Harvard University Press, Cambridge, MA

Heilbron T (2012) Botanical relics of the plantations of Suriname. MSc thesis, University of Amsterdam

Herlein JD (1718) Beschryvinge van de volk-plantinge Zuriname. Meindert Injema, Leeuwarden 
Herskovits MJ, Herskovits FS (1934) Rebel Destiny: among the bush negroes of Dutch Guiana. Emmering, Amsterdam

Howard RC (1979) Monocotyledonae. In: Flora of the Lesser Antilles, Leeward and Windward Islands 3. Arnold Arboretum, Harvard University, Jamaica Plain, pp 504-511

Kambel ER (2006) Policy note on indigenous peoples and Maroons in Suriname. World Bank, Washington

Kawa NC (2012) Magic plants of Amazonia and their contribution to agrobiodiversity. Hum Organ 71:225-233

Linares OF (2002) African rice (Oryza glaberrima): history and future potential. Proc Natl Acad Sci 99:16360-16365

Maréchal R, Masherpa JM, Stainier F (1978) Etude taxonomique d'un groupe complexe d'espèces des genres Phaseolus et Vigna (Papilionaceae) sur la base des données morphologiques et polliniques, traitées par l'analyse informatique. Boissiera 28:1-273

Maxted N (ed) (2012) Agrobiodiversity conservation: securing the diversity of crop wild relatives and landraces. CABI, Wallingford

Maxted N, Mabuza-Dlamini P, Moss H, Padulosj S, Jarvis A, Guarino L (2004) An ecogeographic survey: African Vigna, Systematic and ecogeographic studies of crop genepools 10. IPGRI, Rome

McNeill JR (2003) Europe's place in the global history of biological exchange. Landsc Res 28:33-39

Onwueme IC, Hamon P (2002) Dioscorea cayenensis Lam. In: Oyen LP, Lemmens RHMJ (eds) Record from protabase. Plant Resources of Tropical Africa, Wageningen

Oostindie G (1993) Voltaire, Stedman and Suriname Slavery. Slavery Abolit 14:1-34

Ostendorf FW (1962) Nuttige planten en sierplanten in Suriname. Landbouwproefstation, Paramaribo

Price R (1973) Maroon societies: rebel slave communities in the Americas. The Johns Hopkins University Press, Baltimore

Price R (1983) First-time: the historical vision of an Afro-American people. Johns Hopkins University Press, Baltimore

Price R (1991) Subsistence on the plantation periphery: crops, cooking, and labour among eighteenth century Suriname Maroons. Slavery Abol 12:107-127

Quiroz D, Towns AM, Legba SI, Swier J, Brière S, Sosef MSM, van Andel TR (2014) Quantifying the domestic market in herbal medicine in Benin, West Africa. J Ethnopharmacol 151:1100-1108

Rangan H, Carney JA, Denham T (2012) Environmental history of botanical exchanges in the Indian Ocean world. Environ Hist Camb 18:311-342

Rashford J (2001) Those that do not smile will kill me: the ethnobotany of the ackee in Jamaica. Econ Bot 55:190-211

Reijers M (2014) African heritage in Maroon agriculture: multiple uses of Old World crops among Aucans and Saramaccans. MSc thesis, Wageningen University

Rolander D (2008) Daniel Rolander's journal, the Suriname journal: composed during an exotic journey. In: Hansen L (ed) The Linnaeus apostles: Global Science \& Adventure, vol 3, no 3. IK Foundation, London, pp 1215-1576

Safo Kantaka O (2004) Colocasia esculenta (L.) Schott. In: Grubben GJH, Denton OA (eds) PROTA 2: Légumes. Wageningen, Plant Resources of Tropical Africa, pp 231-236

Stedman JG (1988) Narrative of a five years' expedition, against the revolted negroes of Surinam 1790. Johns Hopkins University Press, Baltimore
St-Hilaire A (2001) Ethnicity, assimilation and nation in plural Suriname. Ethn Racial Stud 24:998-1019

Summer Institute of Linguistics (2003) Languages of Suriname. http://www-01.sil.org/americas/suriname. Accessed 12 Dec 2014

Thoden Van Velzen HUE, Hoogbergen W (2011) Een zwarte vrijstaat in Suriname. De Okaanse samenleving in de achttiende eeuw, KITLV, Leiden

Towns AM, Quiroz D, Guinee L, de Boer HJ, van Andel TR (2014) Volume, value and floristic diversity of Gabon's medicinal plant markets. J Ethnopharmacol 155:1184-1193

Tripathi KK, Govila OP, Warrier R, Ahuja V (2011) Biology of Abelmoschus esculentus L. (Okra). Govt. of India, Department of Biotechnology, New Delhi

Van Andel TR (2010) African Rice (Oryza glaberrima Steud.): lost crop of the enslaved Africans discovered in Suriname. Econ Bot 64:1-10

Van Andel TR, Ruysschaert S (2011) Medicinale en rituele planten van Suriname. KIT Publishers, Amsterdam

Van Andel TR, Dobreff J, Maas PJM (2012a) Ethnobotanical notes from Daniel Rolander's Diarium Surinamicum (1754-1756): are these plants still used in Suriname today? Taxon 61:852-863

Van Andel TR, Veldman S, Maas PJM, Thijsse G, Eurlings M (2012b) The forgotten Hermann Herbarium: a 17th century collection of useful plants from Suriname. Taxon 61:1296-1304

Van Andel TR, Myren B, van Onselen S (2012c) Ghana's herbal market. J Ethnopharmacol 140:368-378

van den Bosch J (1818) Nederlandsche bezittingen in Azia. Amerika en Afrika, Van Cleef, Amsterdam

Van der Burg WJ, de Freitas J, Debrot AO, Lotz LAP (2012) Naturalised and invasive alien plant species in the Caribbean Netherlands: status, distribution, threats, priorities and recommendations. Wageningen, Alterra

Van der Maesen LJG (1990) Pigeonpea: origin, history, evolution and taxonomy. In: Nene YL, Hall SD, Sheila VK (eds) Pigeonpea. CAB International, Wallingford, pp 15-46

Van Dijck P (2013) The impact of the IIRSA road infrastructure programme on Amazonia. Routledge, New York

Van Lier RAJ (1971) Frontier society: a social analysis of the history of Surinam. Martinus Nijhoff, The Hague

Van Proosdij ASJ (2012) Arnoldo's zakflora: wat in het wild groeit en bloeit op Aruba, Bonaire en Curacao. De Walburg Pers, Zutphen

Van Stipriaan A, Polimé T (2009) Kunst van overleven: Marroncultuur uit Suriname. KIT Publishers, Amsterdam

Voeks RA (2013) Ethnobotany of Brazil's African diaspora: the role of floristic homogenization. In: Voeks RA, Rashford J (eds) African ethnobotany in the Americas. Springer, NewYork, pp 395-416

Vossen TE, Towns AM, Ruysschaert S, Quiroz D, van Andel TR (2014) Consequences of the trans-Atlantic slave trade on medicinal plant selection: plant use for cultural bound syndromes affecting children in Suriname and Western Africa. PLoS ONE 9:e112345

Warren G (1667) An impartial description of Surinam upon the continent of Guiana in America. Nathaniel Brook, London

Whitney LD, Imaikalani Bowers FA, Takahashi M (1997) Taro varieties in Hawaii. University of Hawaií, CTAHR, Honolulu 
Zeeland Archives (2013) MCC Slave Voyage the Unity 1761-1763. http://eenigheid.slavenhandelmcc.nl. Accessed 1 Dec 2014
Zeven AC (1998) Landraces: a review of definitions and classifications. Euphytica 104:127-139 